$\mathrm{DOI}$

УДК 633.853.483:631.894

ЭФФЕКТИВНОСТЬ НЕКОРНЕВОЙ ОБРАБОТКИ ПРИ ВЫРАЩИВАНИИ ГОРЧИЦЫ БЕЛОЙ

Наумцева Ксения Викторовна, аспирант кафедры агрономии и агротехнологий, ФГБОУ ВО «Рязанский государственный агротехнологический университет имени П. А. Костычева».

390044. г. Рязань, ул. Костычева, 1.

E-mail: ksyu.dyachuk.93@mail.ru

Виноградов Дмитрий Валерьевич, д-р. биол. наук, проф., зав. кафедрой агрономии и агротехнологий, ФГБОУ ВО «Рязанский государственный агротехнологический университет имени П. А. Костычева».

390044. г. Рязань, ул. Костычева, 1.

E-mail: vdv-rz@rambler.ru

Ключевые слова: горчица, обработка, удобрения, подкормка, урожайность.

Цель исследований - повышение урожайности сортов горчицы белой путем применения многокомпонентных жидких удобрений в условиях Рязанской области. Исследования проводились в 20182019 гг. на полях опытной агротехнологической станции Рязанского государственного агротехнологического университета (УНИЦ «Агротехнопарк»). Почва опытного участка серая лесная. В 2019 году площадь под масличными культурами в Рязанской области составляла свыше 151 тыс. га, посевная площадь горчицы - 9,5 тыс. га. Опыты 1 и 2 закладывались в 4-кратной повторности. Комплексное жидкое удобрение как в опыте 1, так и в опыте 2 обеспечило интенсивный рост растений, увеличило показатели фотосинтеза. Наибольшее число маслосемян в опыте 1 было получено на сорте Люция - вариант Азотовит 1 л/га + Фосфратовит 1 л/га + РауАктив 1 л/га - 20,5 ц/га, что выше, чем в контроле на 3,1 u/2а. Сорт Чайка - 17,4 u/2а, сорт Рапсодия - 18,5 u/2а (в среднем за годы исследований). Опьт 2 характеризовался максимальным увеличением урожайных показателей сорта Люция - 13,1 u/2а (в среднем за 2018-2019 ге.) - на варианте Актив Бор 1л/га + Актив Цинк 1л/га. Исследования 2018-2019 ге. показали, что в практической деятельности агропромьшленного комплекса региона в агроценозах горчицы белой можно использовать многокомпонентные жидкие удобрения Азотовит, Фосфратовит, РауАктив - фаза обработки 2-4 настоящих листа + фаза бутонизации (норма расхода 1,0 л/2а) - и комплексные препараты Актив Цинк и Актив Бор - фаза обработки завязь листовой розетки + фаза бутонизации (норма расхода 1,0 л/2а).

\title{
FOLIAR FEEDING EFFECTIVENESS DURING WHITE MUSTARD CULTIVATION
}

K. V. Naumtseva, Graduate Student of the Department of Agronomy and Agricultural Technologies, FSBEI HE Ryazan State Agrotechnological University named after P. A. Kostychev.

390044, Ryazan, Kostycheva street, 1.

E-mail: ksyu.dyachuk.93@mail.ru

D. V. Vinogradov, Doctor of Biological Sciences, Professor, Head of the Department of Agronomy and Agricultural Technologies, FSBEI HE Ryazan State Agrotechnological University named after P. A. Kostychev.

390044, Ryazan, Kostycheva street, 1.

E-mail:vdvrzn@mail.ru

Keywords: mustard, processing, fertilizers, top dressing, productivity.

The purpose of the research is increasing the yield of white mustard varieties by using complex liquid fertilizers in Ryazan region. The research was conducted in 2018-2019 on the fields of the experimental agro-technological station of Ryazan state agro-technological University («Agrotechno-Park»). The soil of the experimental site is gray forest. In 2019, the area under oil producing crops in Ryazan region was more than 151 thousand hectares, the mustard sown area amounted to 9.5 thousand hectares. Two experiments were performed in 4-fold replication. Complex liquid fertilizer in both experiment 1 and experiment 2 provided intensive plant growth and increased photosynthesis rates. The largest number of oilseeds in experiment 1 was obtained on the Lucium breed, variant Azotovit 1 l/ha + Phosphatovit 1 l/ha + 
Rauactive $1 \mathrm{l} / \mathrm{ha}-20.5 \mathrm{C} / \mathrm{ha}$, which is higher than in the control by $3.1 \mathrm{C} /$ ha. Chaika - breed was $17.4 \mathrm{C} / \mathrm{ha}$ and Rapsodia one $-18.5 \mathrm{C} / \mathrm{ha}$ (on average over the years of research). Experiment 2 was characterized by the maximum increase in yield of the Lucium breed - 13.1 C/ha (on average per 2018-2019) - on the Active Boron one 1 l/ha + Active Zinc $1 \mathrm{l} / \mathrm{ha}$. Studies of 2018-2019, showed that in practice of agriculture in the region in agrocenoses of white mustard can be used complex liquid fertilizer Azotovit, Fosfatami, Reactiv - processing phase from 2 to 4 true leaves + phase budding (consumption rate 1.0 I/ha) and complex preparations, Zinc Asset and Asset Bor - processing phase of button rosette + the budding phase (consumption rate $1.0 \mathrm{l} / \mathrm{ha}$ ).

Большая потребность в высококачественных маслосеменах предопределяет дальнейшее развитие страны, что обуславливает необходимость разработки научно-обоснованных экологически безопасных технологий. Нечерноземная зона России, в которую входит и Рязанская область, благоприятна для выращивания масличных растений [1].

Рынок масличной продукции является важнейшей составляющей и неотъемлемой частью агропродовольственного рынка [2]. Из семян масличных культур вырабатывают растительное масло, которое экологически безопаснее минерального масла. При использовании в качестве биодизельного топлива оно позволяет частично заменить запасы природной нефти, снизить нагрузку углекислого газа на окружающую среду [3].

В настоящее время перспективными масличными культурами считаются горчица сизая (Brassica juncea Czern) и белая (Brassica sinapis alba L) [4]. Оба вида горчицы похожи между собой, однолетние растения семейства Капустные. Эффрективным и популярным сидеральным растением является крестоцветная культура - горчица белая. Использование горчицы позволяет эффективно эксплуатировать сельскохозяйственные угодья [5]. Благодаря быстрому росту и объемной зеленой массе она помогает обогащать почву органикой, азотом и другими минералами, а содержащиеся в ней эфирные масла снижают распространение патогенных грибов и насекомых-вредителей. Особую ценность горчица-предшественник имеет для лука, картофельных, томатных и бобовых плантаций. Данное растение является ценной масличной культурой, которая в перспективе способна завоевать ведущее положение среди группы масличных в регионе. В новых сортах горчицы, к примеру, Ария, Белоснежка, Аврора содержится 35-50\% масла, которое используется при производстве консервов, маргарина, в хлебопекарном и кондитерском деле. Вегетационный период горчицы короткий, что дает возможность использовать ее как промежуточную, пожнивную культуру, в Нечерноземной зоне России. Культура горчица белая довольно холодостойкая и влаголюбивая. Всходы растений горчицы выдерживают заморозки до $-6^{\circ} \mathrm{C}$. Она неприхотлива к плодородию почв, может произрастать на беднах почвах со средней кислотностью.

Посевные площади горчицы в России, по данным Росстата, в 2019 году в хозяйствах всех категорий составляли 382,3 тыс. га, что на 14,4\% (на 48,2 тыс. га) больше, чем в 2018 году. За 5 лет посевные площади увеличились на 98,4\% (на 189,6 тыс. га), за 10 лет - на 279,1\% (на 281,5 тыс. га). В 2001 году площади горчицы составляли 59,0 тыс. га [6].

Общая посевная площадь всех сельскохозяйственных культур в Рязанской области в 2019 году составляла - 918,8 тыс. га (на 35,6 тыс. га больше, чем в 2018 г.). Под масличными культурами, в 2019 году, в Рязанской области было занято свыше 151 тыс. га. Такая площадь масличных в регионе была впервые. Аграрии региона посеяли 56,3 тыс. га подсолнечника (16,4 \% от общей площади), 9,5 тыс. га горчицы (1,0\% от общей площади), 49,7 тыс. га озимого и ярового рапса, 30,4 тыс. га сои, 2,9 тыс. га масличного льна и 1,5 озимого рыжика [7].

При производстве сельскохозяйственной продукции главным показателем является урожайность. Для её повышения применяют листовые подкормки с помощью комплексных удобрений. К преимуществам данного типа внесения удобрений можно отнести:

- устранение десицита недостающих веществ при первых признаках минерального голодания. Внекорневая подкормка (обработка) не является основной, а только добавляет и корректирует количество основных минералов, которые находятся в почве;

- быстрота насыщения листовыми удобрениями, когда микроэлементы в почве находятся в недоступной форме для питания растений и не усваиваются должным образом. Листовая обработка (подкормка) способна повышать урожайность при правильном внесении питательных веществ. 
В настоящее время возрастает интерес экспертов и производственников к применению некорневой подкормки растений. В основу должны быть положены экономичность, эффективность и качество, в частности внедрение инновационных технологий. Это и определило актуальность и направление исследований.

Цель исследований - повышение урожайности сортов горчицы белой путем применения многокомпонентных жидких удобрений в условиях Рязанской области.

Задачи исследований - изучить действие многокомпонентных жидких удобрений на рост, развитие, урожайность сортов горчицы белой.

Материалы и методы исследований. Исследования проведены в 2018-2019 гг. на полях опытной агротехнологической станции ФГБОУ ВО Рязанского государственного агротехнологического университета имени П. А. Костычева (УНИЦ «Агротехнопарк»). Почва опытного участка серая лесная. Содержание гумуса - 2,5-3,1, фосфора - в среднем по опытам - 12,1-12,5 мг/100 г почвы, калия - 8,39,1 мг/100 г почвы. В среднем по слою почвы 0-40 см кислотность составляла рH 5,2-5,3.

Объект исследований - сорта горчицы белой: Рапсодия (ГНУ ВНИИ рапса, г. Липецк), Люция (оригинатор Пензенский НИИ селского хозяйства), Чайка (семеноводство сорта ведётся научным институтом селекции, г. Николаев, Украина).

Учеты и наблюдения в период вегетации горчицы проведены на основе «Методики госсортоиспытания сельскохозяйственных культур» (1985). Выполняли математическую обработку результатов с помощью программ на ЭВМ, а также по Б. А. Доспехову (1985). В опытах 1 и 2 общая площадь одной делянки составила $30 \mathrm{~m}^{2}$, учетная - $20 \mathrm{~m}^{2}$. Повторность четырехкратная.

Опыт 1. Продуктивность горчицы белой в зависимости от применения микробиологических удобрений. В качестве объекта исследования были взяты сорта горчицы белой: Рапсодия, Люция, Чайка. В исследованиях применялись жидкие удобрения: Интермаг профи, Азотовит, Фосфратовит, РауАктив по предусмотренной схеме. Схема опыта:

1) Контроль - без обработки.

2) Листовая подкормка. Интермаг Профи 1 л/га - фаза 2-4 настоящих листа + фаза бутонизации + инсектицид.

3) Листовая подкормка. Азотовит 1 л/га + Фосфратовит 1 л/га - фаза 2-4 настоящих листа.

4) Листовая подкормка. Интермаг Профи 1 л/га + Азотовит 1 л/га + Фосфатовит 1 л/га - фаза 2-4 настоящих листа.

5) Листовая подкормка. Азотовит 1 л/га + Фосфратовит 1 л/га - фраза 2-4 настоящих листа + РауАктив 1 л/га - фаза бутонизация - цветение (30\% от максимальной листовой поверхности до цветения). Расход рабочей жидкости 200 л/га.

Характеристика применяемых препаратов:

Азотовит - жидкое микробиологическое удобрение. Свободноживущие азотфиксирующие бактерии. Активизируют прорастание семян, способствуют интенсивному росту и развитию растений. Снижает токсическое действие после обработки растения химическими препаратами. Безопасное, экологичное питание растений.

Фосфатовит - жидкое микробиологическое удобрение, обладает фосффатомобилизирующими свойствами почвенных бактерий. Переводит недоступный фоссрор и калий в легкодоступные формы для растений. Увеличивает энергию прорастания и роста растений. Формирует дополнительный урожай, увеличивается интенсивность, и растения эффективнее используют питательные вещества. Состав препарата имеет возможность повлиять на прекращение процессов зафосфачивания почв. Безопасное, экологичное питание растений.

Интермаг Профи - концентрированное комплексное жидкое микроудобрение, предназначенное для всех масличных культур. Разработано с учетом питательных требований масличных. Содержит грамотно сбалансированный набор микроэлементов, полностью отвечающих питательным требованиям масличных культур. Микроэлементы, входящие в состав препарата, находятся в легкоусваиваемой растением хелатной форме. Это гарантирует качественное, полное усваивание поверхностью растений. 
РауАктив - жидкое многокомпонентное удобрение. В состав препарата входит сбалансированный набор макро- и микроэлементов, витамины и аминокислоты. Проявляет эфффективное влияние на рост и развитие растений.

Опыт 2. Эффрективность применения микроудобрений в посевах горчицы белой. В качестве объекта исследования были взяты сорта горчицы белой: Рапсодия и Люция. В исследованиях применялись жидкие удобрения: Актив Бор, Актив Цинк по предусмотренной схеме. Схема опыта:

1) Контроль - без обработки.

2) Листовая подкормка. Актив Бор 1 л/га - фаза завязь листовой розетки + фаза бутонизации.

3) Листовая подкормка. Актив Цинк 1 л/га - фаза завязь листовой розетки + фаза бутонизации.

4) Листовая подкормка. Актив Бор 1 л/га + Актив Цинк 1 л/га - фаза завязь листовой розетки + фаза бутонизации.

Характеристика применяемых препаратов:

Актив-Бор - жидкое комплексное удобрение с повышенным содержанием бора. Препарат для внекорневой подкормки (обработки) сельскохозяйственных культур в период роста и формирования плодов. Способствует формированию высоких урожаев, отзывчивых на внесение бора для культур. Внесение удобрения Актив-Бор обеспечивает поступление продуктов фотосинтеза во все части растения, включая его плоды и зерно, что значительно повышает объемы и качество урожая. Массовая доля питательных веществ, не менее: азот (N) 50 г/л, бор (B) 133 г/л.

Актив-Цинк - жидкое комплексное удобрение с повышенным содержанием цинка. Препарат для внекорневой подкормки сельскохозяйственных культур. Достаточное поступление жизненно важного микроэлемента помогает нормализовать процессы обмена веществ и улучшить биосинтез витаминов и гормона роста растений. Благодаря применению Актив-Цинк значительно повышается иммунитет и стрессоустойчивость сорта. Значительно улучшает способность влагоудержания и усвоения фоссрора. Массовая доля питательных веществ: азот (N) 65 г/л, фоосфор (P) 25 г/л, сера (S) 70 г/л, цинк (Zn) 142 г/л. Доза внесения препаратов 1 л/га. Расход рабочей жидкости - 200 л/га.

Агротехнические мероприятия по возделыванию горчицы выстраивались в соответствии с существующими зональными рекомендациями. В подготовку почвы входило: лущение стерни, зяблевая вспашка (на глубину пахотного слоя 20-22 см), ранневесеннее боронование с последующей культивацией (10-12 см). Предпосевная культивация (глубина 2-4 см) с внесением удобрений, фон $\mathrm{N}_{125} \mathrm{P}_{60} \mathrm{~K}_{60}$. Посев осуществлялся в первую декаду мая. Норма высева семян - 2,5 млн шт. всхожих семян/га. Глубина заделки семян - 2 см. Способ посева - рядовой, сеялкой ССНТ-16. В опыте 1 в фазу 2-4 настоящих листа и фазу бутонизации производились листовые подкормки комплексными препаратами Азотовит, Фосфратовит, РауАктив, Интермаг Профи. В опыте 2 в фразу завязи листовой розетки и фазу бутонизации производились листовые подкормки комплексными препаратами типа Актив-Бор, Актив-Цинк.

В опытах от фразы всходов до фразы бутонизации проводили обработку инсектицидами против вредителей культуры. Осуществляли обработку инсектицидом Фастак 0,15 л/га (расход рабочей жидкости $250 \mathrm{л} / г$ ) для уничтожения крестоцветной блошки и рапсового цветоеда. Уборка механизировано - Тарион-2010. Высота среза находилась на уровне 6-8 см.

Результаты исследований. Всхожесть и энергия прорастания являются важными показателями в определении качества семенного материала.

В опыте 1 период появления всходов у горчицы белой составлял 6-10 дней. При благоприятных условиях всходы появлялись раньше. Показатели посевных качеств сортов горчицы представлены в таблице 1.

Таблица 1

Посевные качества сортов горчицы белой, среднее, \%, 2018-2019 гг.

\begin{tabular}{|l|c|c|c|c|}
\hline \multirow{2}{*}{ Сорт } & \multirow{2}{*}{ Энергия прорастания, \% } & \multirow{2}{*}{ Лабораторная всхожесть, \% } & \multicolumn{2}{|c|}{ Полевая всхожесть } \\
\cline { 4 - 5 } & & & шт./М² & $\%$ \\
\hline Люция & 91,0 & 95,5 & 235,9 & 94,3 \\
\hline Рапсодия & 89,0 & 94,0 & 233,3 & 93,3 \\
\hline Чайка & 88,5 & 95,5 & 233,4 & 94,0 \\
\hline
\end{tabular}


Сорта горчицы белой имели высокую энергию прорастания и всхожесть (табл. 1). В среднем, наибольшая полевая всхожесть была получена на варианте с сортом Люция - 235,9 шт./М². Это сформировало повышение посевных качеств сортов, а подходящие погодные условия и соблюдение агротехнических приемов способствовали получению высокого урожая.

Метеорологические условия, в среднем за годы исследований, оказывали прямое влияние на наступление фенофаз. Ранние всходы наблюдали у сорта Люция. Вегетационный период сорта, в среднем, составлял 90 дней. Длительность периода от посева семян до всходов - 6-8 дней. Наступление фазы цветения приходилось на 20-25 день после посева и длилась она 25-30 дней. Период формирования плодов и созревание семян в плодах наблюдался в конце июля - первой половине августа. Следовательно, фаза полного созревания горчицы белой наступает во II-й декаде августа при посеве в первую декаду мая.

Вегетационный период сортов горчицы белой Рапсодия и Чайка, составлял 64-76 дней и 83 дня, соответственно.

Полевые исследования применения жидких удобрений в 2018-2019 годах выявили их высокую эффективность в посевах горчицы белой. Некорневая обработка положительно влияла на сохранность растений горчицы белой. Лучшие значения сохранности отмечены у сорта Люция в 2019 году (вариант Азотовит + Фосфратовит + РауАктив) - 230,7 шт./м² ,что выше значения в контрольном варианте на 7 шт./M².

Наблюдения за растениями горчицы белой показали, что биоудобрения влияли на высоту растений. Более интенсивный рост отмечался у растений сорта Люция - 89,0 см (вариант Азотовит + Фоссратовит + РауАктив), что выше показателя контрольного варианта на 3 см (в среднем за годы исследований).

Некорневая обработка повышала фотосинтетический потенциал и характеристики структуры урожая. Максимальное формирование листового органа отмечено у растений сорта Люция - 9,9 тыс.м²/га, что на 0,4 тыс.м²/га больше, чем у растений сорта Рапсодия, и на 0,8 тыс.м²/га, чем у растений сорта Чайка (в среднем за годы исследований). Поверхность листьев, в расчете на единицу площади, имела несущественную разницу между сортами.

Полученные данные по структурному анализу. Масса 1000 семян колебалась по сортам несущественно - 5,0-5,1 г (соответствует средним значениям этих сортов). Использование микроудобрений способствовало лучшему развитию плодов растений. Максимальное число плодов наблюдали у сорта Люция в 2019 году - 38,0 шт./растение ( в варианте Интермаг Профи + Азотовит + Фосфратовит и в варианте Азотовит + Фосфратовит + РауАктив), что выше, чем в контроле на 5 шт./растение. Наибольшее количество зерен в плоде было получено в 2019 году сортом Люция в варианте Азотовит + Фосфратовит + РауАктив - 6 шт. в одном стручке, что выше, чем в контрольном варианте в 1,5 раза.

Урожайности сортов горчицы белой представлены на рисунке 1.

Применение биоудобрений существенно воздействовало на продуктивность растений горчицы белой (рис. 1). Наибольшее число маслосемян было получено сортом Люция, вариант Азотовит + Фосфратовит + РауАктив, - 20,5 ц/га, что выше, чем в контроле на 3,1 ц/га, сортом Чайка - 17,4 ц/га, сортом Рапсодия - 18,5 ц/га (в среднем за годы исследований).

В 2018-2019 гг. наблюдались благоприятные погодные условия. Это способствовало существенному росту и развитию растений, а листовая подкормка микроудобрениями - достоверному повышению урожайности, в сравнение с контрольным вариантом.

Во опыте 2, с изучением препаратов Актив-Цинк и Актив-Бор, период появления всходов у горчицы белой составлял, в среднем, 8-10 дней. Полевая всхожесть зависела от температуры почвы на глубине посева семян, температуры воздуха, влажности почвы, наличия почвенных вредителей, а также почвенной корки. Для получения высококачественных семян горчицы белой необходим тщательный своевременный уход за посевами.

Исследуемые сорта горчицы белой, по вариантам опыта, превышали контроль. Высота стеблестоя сортов горчицы белой составляла 73,8-80,2 см (рис. 2). 


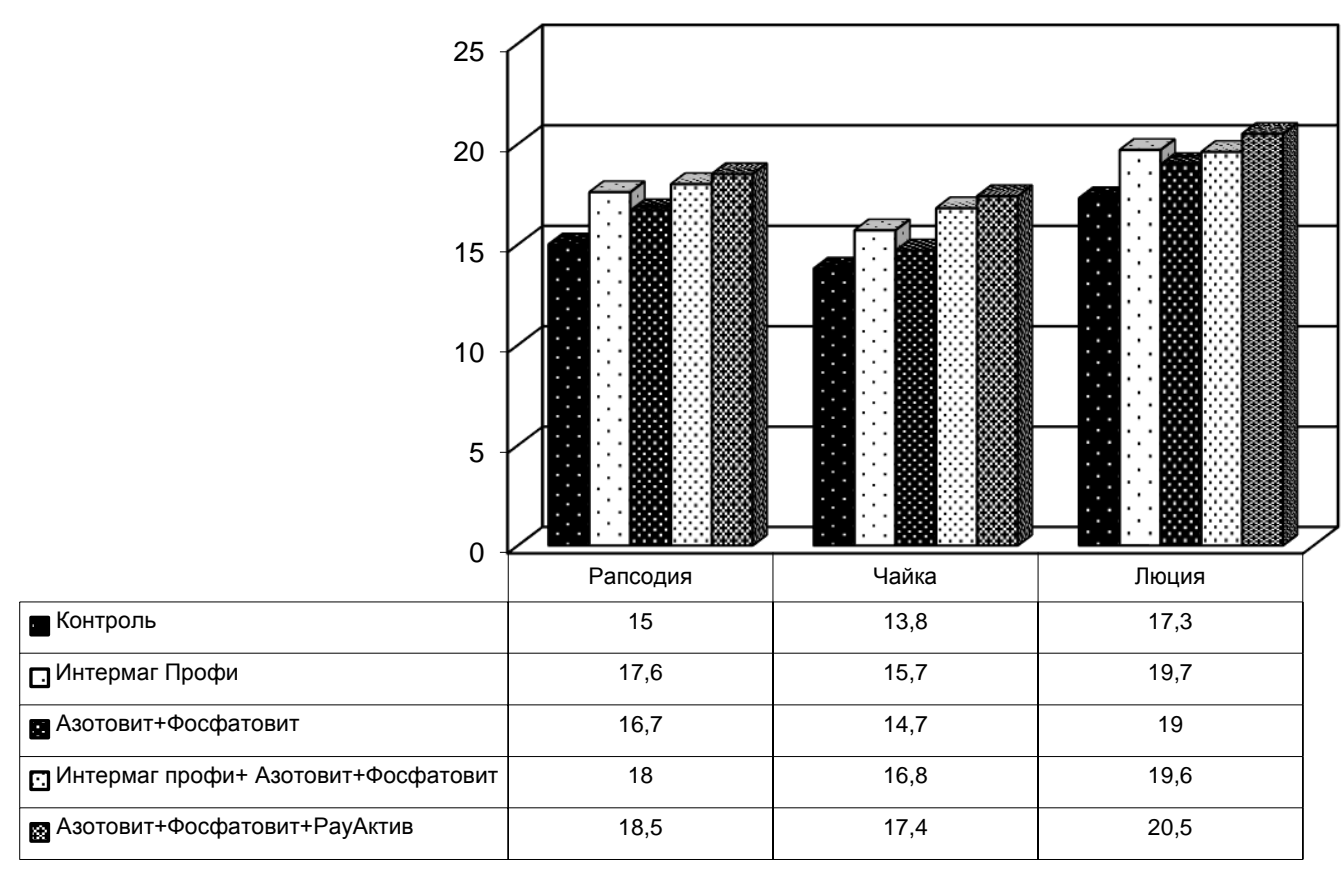

Рис. 1. Влияние микроудобрений на урожайность горчицы белой, ц/га, среднее за 2018-2019 гг.

Максимальная высота растений отмечалась в 2019 году у горчицы сорта Люция - 80,2 см, что больше на 8 см, чем у растений сорта Рапсодия. Под влиянием неустойчивых климатических условий 2019 года наблюдалось угнетение ростовых процессов сорта Рапсодия.

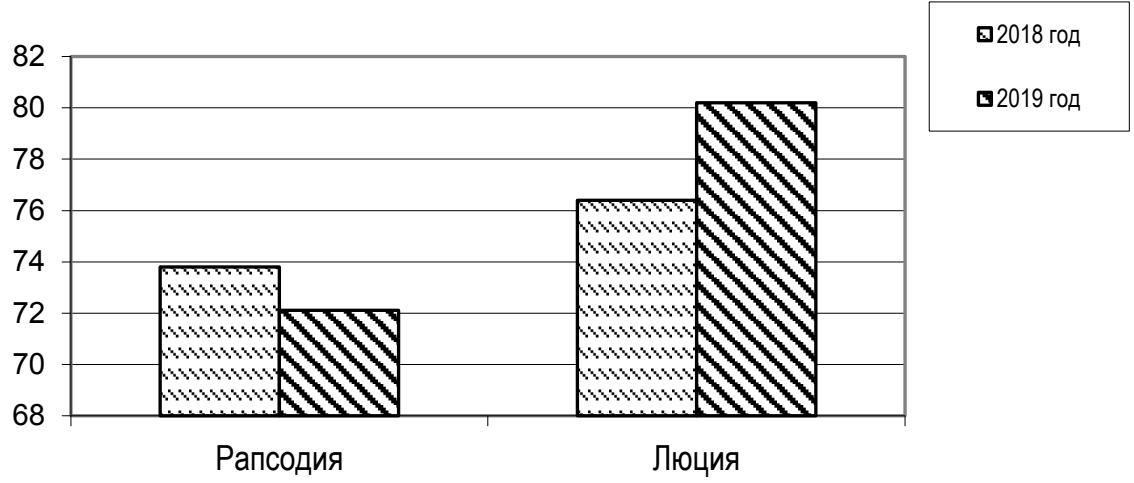

Рис. 2. Высота растений сортов горчицы белой, см, вариант Актив-Бор + Актив-Цинк

Показатель массы 1000 семян находился в пределах 4,9-5,3 г (соответствует средним значениям этих сортов). Некорневая обработка жидкими удобрениями в фазу вегетации завязь листовой розетки спровоцировала интенсивный вегетативный рост и развитие растений горчицы белой. Листовая подкормка в фазу бутонизации способствовала лучшему сохранению растений (сорт Люция - 219,2 шт./М²), увеличению количества семян в стручках на 2,8 г и массы 1000 семян на 1,8 г (средние показатели за 2018-2019 г).

Данные анализа урожайности приведены в таблице 2. Применение комплексных жидких удобрений увеличивало урожайность семян горчицы белой на всех сортах, по сравнению с контролем. Максимальное количество семян было получено сортом Люция (средняя урожайность 13,1 ц/га) на варианте Актив-Бор + Актив-Цинк. Применение препарата Актив-Цинк обеспечило увеличение урожайности горчицы сорта Люция на 1,4 ц/га, по сравнению с контрольным вариантом. 
Урожайность горчицы белой в зависимости от варианта обработки агрохимикатом

\begin{tabular}{|c|c|c|c|c|}
\hline \multirow{2}{*}{$\begin{array}{l}\text { Сорт } \\
\text { (фактор A) }\end{array}$} & \multirow{2}{*}{$\begin{array}{l}\text { Вариант обработки } \\
\text { (фактор В) }\end{array}$} & \multicolumn{3}{|c|}{ Урожайность, ц/га } \\
\hline & & 2018 г. & 2019 г. & среднее \\
\hline \multirow[t]{4}{*}{ Рапсодия } & Контроль (без обработок) & 11,0 & 10,9 & 10,9 \\
\hline & Актив-Бор & 11,9 & 12,0 & 11,9 \\
\hline & Актив-Цинк & 12,1 & 12,3 & 12,2 \\
\hline & Актив-Бор + Актив-Цинк & 12,9 & 12,2 & 12,5 \\
\hline \multirow[t]{4}{*}{ Люция } & Контроль (без обработок) & 11,0 & 11,4 & 11,2 \\
\hline & Актив-Бор & 12,3 & 12,1 & 12,2 \\
\hline & Актив-Цинк & 12.5 & 12,8 & 12,6 \\
\hline & Актив-Бор + Актив-Цинк & 13,0 & 13,2 & 13,1 \\
\hline \multicolumn{2}{|c|}{ НСР 05 взаимодействия AB } & \multicolumn{3}{|c|}{0,22} \\
\hline \multicolumn{2}{|c|}{ по фактору А (сорт) } & 0,12 & \multicolumn{2}{|l|}{0,11} \\
\hline \multicolumn{2}{|c|}{ по фактору В (агрохимикат) } & 0,17 & \multicolumn{2}{|l|}{0,15} \\
\hline
\end{tabular}

Заключение. В среднем за два года исследований применение жидких удобрений позволило получить существенную прибавку маслосемян горчицы белой. В опыте 1 максимальную урожайность (20,5 ц/га) показал вариант с сортом Люция - Азотовит 1 л/га + Фосфратовит 1 л/га + РауАктив 1 л/га. В опыте 2, с изучением препаратов Актив-Бор и Актив-Цинк, максимальная урожайность (13,1 ц/га) получена на варианте с сортом Люция - Актив-Бор 1 л/га + Актив-Цинк 1л/га. Для получения устойчивых урожаев необходимо использовать многокомпонентные жидкие удобрения. На основании исследований 2018-2019 гг. в практической деятельности агропромышленного комплекса региона в агроценозах горчицы белой можно использовать многокомпонентные жидкие удобрения Азотовит, Фоссратовит, РауАктив - фаза обработки 2-4 настоящих листа + фаза бутонизации, с нормой расхода 1,0 л/га и комплексные препараты Актив-Цинк и Актив-Бор - фаза обработки завязь листовой розетки + фаза бутонизации, с нормой расхода 1,0 л/га.

\section{Библиографический список}

1. Виноградов, Д. В. Урожайность горчицы белой при использовании современных жидких удобрений в Нечерноземной зоне России / Д. В. Виноградов, К. В. Наумцева, Е. И. Лупова [и др.] // Вестник Рязанского государственного агротехнологического университета имени П. А. Костычева. - 2019. - №4. - С.132-136.

2. Виноградов, Д. В. Перспективы и основные направления развития производства масличных культур в Рязанской области / Д. В. Виноградов, П. Н. Ванюшин // Вестник Рязанского государственного агротехнологического университета имени П. А. Костычева. - 2012. - №1 - С. 62-65.

3. Виноградов, Д. В. Возможность использования масличных культур в качестве сырья для производства экологически чистого топлива / Д. В. Виноградов, Н. В. Бышов, Е. И. Лупова // Молодёжь в поисках дружбы : материалы Республиканской научно-практической конференции. - Бохтариён : Институт энергетики Таджикистана, 2017. - С. 28-33.

4. Наумцева, К. В. Использование биоудобрений в посевах горчицы / К. В. Наумцева, Д. В. Виноградов // Приоритетные направления научно-технологического развития агропромышленного комплекса России : материалы Национальной научно-практической конференции. - Рязань : Издательство Рязанского государственного агротехнологического университета, 2019. - Часть III. - С. 506-509.

5. Наумцева, К. В. Производство горчицы в Рязанской области / К. В. Наумцева, Е. И. Лупова // Ресурсоэнергосберегающий сорт как эфффективный фактор ведения устойчивого земледелия Рязанской области. - Подвязье : Рязанский НИИ сельского хозяйства, 2018. - С. 124-128.

6. Посевные площади горчицы в России в 2019 году [Электронный ресурс]. - Режим доступа: https://abcentre.ru/news/posevnye-ploschadi-gorchicy-v-rossiiitogi-2019-goda (дата обращения: 22.03.2020).

7. Рязань: успехи сельских тружеников региона [Электронный ресурс]. - Режим доступа: https://www.grainprice.ru/news/tag/1/160-ryazanskaya-oblast (дата обращения 22.03.2020).

\section{References}

1. Vinogradov, D. V., Naumtseva K. V., Lupova E. I., Sokolov A. A., \& Antoshina O. A. (2019). Urozhainost gorchici beloi pri ispolizovanii sovremennikh zhidkih udobrenii v Nechernozemnoi zone Rossii [Productivity of white mustard when using modern liquid fertilizers in the non-Chernozem zone of Russia]. Vestnik Riazanskogo gosudarstvennogo agro-tekhnologicheskogo universiteta. P. A. Kostycheva - Herald of Ryazan State Agrotechnological University Named after P.A. Kostycheva, 4, 132-136 [in Russian]. 
2. Vinogradov, D. V., \& Vanyushin, P. N. (2012). Perspektivi I osnovniie napravleniia razvitiia proizvodstva maslichnikh kulitur v Riazanskoi oblasti [Prospects and main directions of development of oilseed production in the Ryazan region]. Vestnik Riazanskogo gosudarstvennogo agro-tekhnologicheskogo universiteta. P. A. Kostycheva Herald of Ryazan State Agrotechnological University Named after P. A. Kostycheva, 1, $62-65$ [in Russian].

3. Vinogradov, D. V., Byshov, N. V., \& Lupova, E. I. (2017). Vozmozhnost ispolizovaniia maslichnikh kulitur v kachestve siriia dlia proizvodstva ekologicheski-chistogo topliva [Possibility of using oilseeds as raw materials for the production of environmentally friendly fuel]. Youth in search of friendship '17: materiali Respublikanskoi nauchnoprakticheskoi konferencii - materials of the Republican scientific and practical conference. (pp. 28-33). Bokhtarien: Institute of energy of Tajikistan [in Russian].

4. Naumtseva, K. V., \& Vinogradov, D. V. (2019). Ispolizovanie bio-udobrenii v posevah gorchici [Use of biofertilizers in mustard crops]. Priority directions of scientific and technological development of the agro-industrial complex of Russia '19: materiali Nacionalinoi nauchno-prakticheskoi konferencii - materials of the National scientific and practical conference. (pp. 506-509). Ryazan: PC Ryazan state agrotechnological University [in Russian].

5. Naumtseva, K. V., \& Lupova, E. I. (2018). Proizvodstvo gorchici v Ryazanskoi oblasti [Mustard Production in the Ryazan region]. Resource-energy-saving variety as an effective factor of sustainable agriculture in the Ryazan region. (pp. 124-128). Podvyaze: Ryazan research Institute of agriculture [in Russian].

6. Posevniie ploshchadi gorchici v Rossii v 2019 godu [Sown areas of mustard in Russia in 2019].ab-centre.ru. Retrieved from: https://ab-centre.ru/news/posevnye-ploschadi-gorchicy-v-rossiiitogi-2019-goda [in Russian].

7. Ryazan: uspekhi seliskih truzhenikov regiona [Ryazan: success of rural workers of the region]. Grain price.ru. Retrieved from: https://www.grainprice.ru/news/tag/1/160-ryazanskaya-oblast [in Russian]. 